\title{
PENGEMBANGAN MAGIC CROSSWORD PUZZLE SEBAGAI MEDIA PEMBELAJARAN IPA UNTUK SISWA KELAS V SEKOLAH DASAR
}

\author{
Ifa Seftia Rakhma. W. ${ }^{\bowtie}$, Unik Widyaningsih, Lilik Mawartiningsih
}

Prodi Pendidikan Guru Sekolah Dasar, Fakultas Keguruan dan Ilmu Pendidikan

Universitas PGRI Ronggolawe Tuban, Indonesia

\section{Info Artikel}

Sejarah Artikel:

Diterima September 2016

Disetujui November 2016

Dipublikasikan Desember 2016

\section{Keywords:}

magic crossword puzzle media, natural phenomena

\begin{abstract}
The purpose of this research is to develop magic crossword puzzle media in the material of natural phenomena. This research is a Research and Development. Implementation magic crossword puzzle media using one group pretest-posttest control design with the subjects are fifth grade students SDN 2 Gedong Mulyo Mulyo academic year 2016/2017. The results magic crossword puzzle media consists of two parts, front page and back page. The front page is crossword puzzle and the back page is pieces of pape. The results validate from two validators are media developed by the researchers included in the category of valid use in the fifth grade of elementary school. Magic crossword puzzle effective in material natural phenomena from the pretest result is $55,56 \%$ posttest result is $94,4 \%$. Students activity is $32 \%$ and teacher activity is $38 \%$. Students also give good respon to magic crossword puzzle meda.
\end{abstract}

\begin{abstract}
Abstrak
Tujuan dari penelitian ini adalah mengembangkan media magic crossword puzzle pada materi peristiwa alam untuk siswa kelas $\mathrm{V}$ sekolah dasar. Penelitian ini merupakan penelitian pengembangan (Research and Development). Implementasi media menggunakan one group pretest-postest control design dengan subjek kelas V SDN 2 Gedong Mulyo kecamatan Lasem kabupaten Rembang tahun pelajaran 2016/ 2017. Hasil penelitian pengembangan media magic crossword puzzle dalam bentuk persegi panjang ukuran $20 \mathrm{~cm}$ x $30 \mathrm{~cm}$ yang terdiri dari dua bagian yaitu bagian depan dan bagian belakang. Bagian depan berupa teka-teki silang dan bagian belakang berupa potongan-potongan gambar. Berdasarkan hasil penilaian media yang dilakukan oleh 2 validator, media magic crossword puzzle termasuk dalam kategori valid. Penerapan metode demonstrasi dengan media magic crossword puzzle efektif digunakan untuk pembelajaran materi peristiwa alam, dapat dilihat dari ketuntasan klasikal pada nilai pretes yaitu sebesar 55,56\% kemudian pada setelah menerapkan magic crossword puzzle naik menjadi 94,4\%. Aktivitas siswa sebesar $38 \%$ dan aktivitas guru sebesar 32\%, menunjukkan media magic crossword puzzle efektif digunakan dalam pembelajaran IPA. Respon siswa terhadap pembelajaran IPA materi peristiwa alam melalui metode demonstrasi dengan media magic crossword puzzle menunjukkan respon yang baik dari siswa kelas V SD N 2 Gedongmulyo.
\end{abstract}

\begin{tabular}{lr}
\hline Alamat korespondensi: & p-ISSN 2087-9385 \\
Program Studi Pendidikan Guru Sekolah Dasar & e-ISSN 2528-696X \\
Fakultas Keguruan dan Ilmu Pendidikan Universitas Muria Kudus & \\
Kampus UMK Gondangmanis, Bae Kudus Gd. L. It I PO. BOX 53 & \\
Kudus & \\
Tlp (0291) 438229 ex.147 Fax. (0291) 437198 & \\
E-mail: ifaseftia@gmail.com &
\end{tabular}




\section{PENDAHULUAN}

Kondisi geografis dan geologis Indonesia dari Sabang sampai Merauke, dari Miangas sampai Pulau Rote, merupakan anugerah Tuhan yang patut disyukuri. Di balik kekayaan sumber daya alam yang dimiliki, kondisi geografis dan geologis Indonesia juga menghadirkan sejumlah fenomena dan gejolak alam. Indonesia sebagai negara kepulauan dengan iklim tropis, memiliki curah hujan tinggi dengan waktu yang singkat, sehingga berpotensi menimbulkan bencana banjir dan tanah longsor (Naryanto, 2011:21). Kerugian yang disebabkan oleh bencana semakin besar, dengan terus meningkatnya frekuensi, intensitas, dan magnitude bencana. Ironisnya, masih banyak penduduk yang menganggap bahwa bencana itu merupakan suatu takdir. Kondisi tersebut merupakan gambaran bahwa paradigma konvensional masih kuat dan berakar di masyarakat. Oleh karena itu, upaya sosialisasi tentang fenomena kebencanaan, upaya pencegahan risiko dan mitigasi bencana pada semua lapisan masyarakat perlu terus didorong lebih maju agar dampak bencana dapat diminimalkan. Salah satu anggota masyarakat yang menjadi obyek sosialisasi adalah siswa sekolah dasar. Hal tersebut diperkuat oleh pernyataan Fatimah (2007: 1) yang menyebutkan bahwa siswa sekolah dasar merupakan generasi penerus bangsa sehingga mereka harus memiliki kesadaran tinggi untuk meminimalkan dampak bencana alam. Siswa yang dapat menerapkan ilmu pengetahuan yang telah diperoleh di bangku sekolah dalam kehidupan sehari-hari jauh lebih bermanfaat daripada siswa yang hanya memperoleh nilai bagus namun tidak dapat menerapkan ilmu yang diperoleh. Selama ini bahan ajar dan media pembelajaran yang diberikan kepada siswa belum sepenuhnya membuat pembelajaran menjadi bermakna.

Menurut Susanto, (2012:45) media pembelajaran adalah media yang mencakup segala sesuatu yang dapat membantu siswa dan guru untuk mencapai tujuan pembelajaran. Media pembelajaran akan mempermudah siswa dalam menerima materi pembelajaran (Sapriati, dkk., 2011:5) Berdasarkan hasil observasi kegiatan belajar mengajar mata pelajaran IPA kelas V SD Negeri 2 Gedongmulyo Kecamatan Lasem Kabupaten Rembang, bahwa metode ceramah yang mendominasi pembelajaran. Siswa menjadi pasif dan pembelajaran IPA menjadi membosankan bagi siswa karena menghafalkan konsep, fakta, dan hukum tidak menarik bagi mereka (Sudjana, 2009: 2). Bagi siswa yang daya ingatnya rendah akan sulit mengingat konsep, fakta, dan hukum IPA yang telah dipelajari.
Keadaan demikian akan berpengaruh terhadap rendahnya hasil belajar siswa. Rendahnya hasil belajar IPA pada Kelas V SD N 2 Gedongmulyo disebabkan oleh beberapa faktor, diantaranya adalah kebiasaan pendidik hanya menggunakan metode ceramah sehingga terkesan monoton dan cenderung pasif, pembelajaran berlangsung searah dan kurang melibatkan keaktifan siswa. Peran guru cenderung dominan sehingga partisipasi siswa dalam proses pembelajaran sangat sedikit dan siswa cenderung tidak tertarik untuk mendengarkan penjelasanpenjelasan guru.

Berdasarkan masalah di atas, maka peneliti berupaya menerapkan metode demonstrasi dengan media Magic Crossword Puzzle sebagai salah satu inovasi pembelajaran bermakna yang mengacu pada pembelajaran aktif, inovatif, kreatif, efektif, dan menyenangkan (Rakhmadani, dkk., 2013:4). Alasan penggunaan media pembelajaran ini mengutamakan permainan untuk mendapatkan materi dan konsep-konsep dalam IPA, sesuai pendapat Wasgito dan Wayan (2014: 41). Bukan hanya hafalan yang daya tahan ingatnya lebih rendah, namun siswa akan tidak sengaja menghafal konsep yang telah dipelajari dengan permainan teka-teki media magic crossword puzzle.

Permasalahan dalam penelitian ini adalah: (1) Bagaimanakah media magic crossword puzzle yang dikembangkan sebagai media pembelajaran materi peristiwa alam untuk siswa kelas V? (2) Seberapa besar tingkat kevalidan media magic crossword puzzle yang dikembangkan? (3) Apakah media magic crossword puzzle efektif digunakan sebagai media dalam pembelajaran materi peristiwa alam?

\section{METODE PENELITIAN}

Penelitian pengembangan ini menggunakan prosedur penelitian Research \& Development ( $\mathrm{R} \& \mathrm{D})$ yang dikembangkan Sugiyono (2010: 434) dan telah disederhanakan ke dalam tiga tahapan utama (lihat gambar 1), yaitu tahap pendahuluan (kajian pustaka, deskripsi dan analisis temuan), tahap pengembangan (desain produk awal, uji ahli, analisis dan revisi, uji terbatas, analisis dan penyempurnaan, dan produk hipotetik), dan tahap evaluasi (implementasi produk dan produk final).

Penilaian kevalidan media dilakukan oleh 2 orang dosen di Universitas PGRI Ronggolawe Tuban. Uji terbatas media magic crossword puzzle diterapkan pada siswa kelas V SDN 2 Gedongmulyo tahun pelajaran 2016/ 2017 yang telah mempelajari materi peristiwa alam. Implementasi media transvisi menggunakan desain one group pretest-postest control design 
dengan subjek kelas V SDN 2 Gedongmulyo tahun pelajaran 2016/ 2017. Keefektifan media magic crossword puzzle ditunjukkan dari hasil belajar, aktivitas siswa, aktivitas guru dan respon siswa terhadap media magic crossword puzzle.

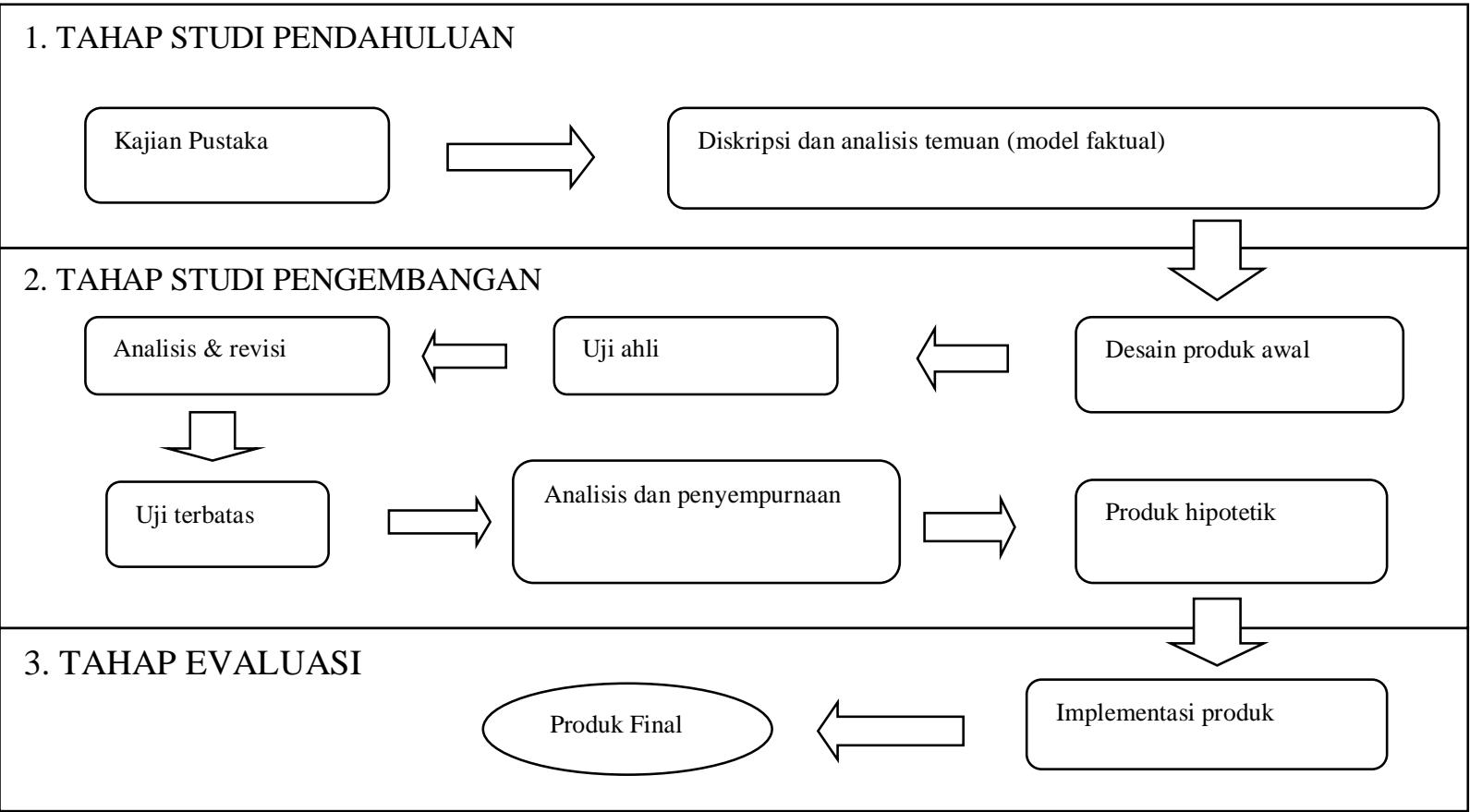

Gambar 1. Proses Pengembangan Media Magic Crossword Puzzle

\section{Pengamatan Aktivitas Siswa Uji Terbatas}

Data aktivitas siswa diperoleh dengan mengisi lembar observasi aktivitas siswa. Pengamatan aktivitas siswa dilakukan oleh dua orang pengamat, yaitu peneliti dan observer. Berikut disajikan persentase aktivitas siswa pada uji terbatas.

Tabel 1. Persentase Aktivitas Siswa pada Uji Terbatas

\begin{tabular}{|c|c|c|c|c|c|}
\hline \multirow{2}{*}{ No } & \multirow{2}{*}{ Aspek Yang Diamati } & \multicolumn{2}{|c|}{ Penilaian } & \multirow{2}{*}{ Persentase } & \multirow{2}{*}{ Ket. } \\
\hline & & $\mathrm{P} 1$ & P2 & & \\
\hline 1 & $\begin{array}{l}\text { Mendengarkan atau memperhatikan penjelasan } \\
\text { guru }\end{array}$ & 2 & 3 & $23 \%$ & Baik \\
\hline 2 & $\begin{array}{l}\text { Siswa menjawab pertanyaan yang diberikan } \\
\text { oleh guru }\end{array}$ & 2 & 3 & $24 \%$ & Baik \\
\hline 3 & $\begin{array}{l}\text { Siswa mengikuti arahan atau petunjuk dari guru } \\
\text { untuk membuat kelompok }\end{array}$ & 2 & 3 & $24 \%$ & Baik \\
\hline 4 & $\begin{array}{l}\text { Siswa mendengarkan dan memperhatikan } \\
\text { penjelasan guru tentang prosedur penggunaan } \\
\text { media magic crossword puzzle }\end{array}$ & 2 & 3 & $24 \%$ & Baik \\
\hline 5 & $\begin{array}{l}\text { Siswa menerima lembar kerja kelompok } \\
\text { berbentuk magic crossword puzzle }\end{array}$ & 2 & 3 & $23 \%$ & Baik \\
\hline 6 & $\begin{array}{l}\text { Kerjasama dalam mengerjakan magic } \\
\text { crossword puzzle }\end{array}$ & 2 & 3 & $24 \%$ & Baik \\
\hline 7 & $\begin{array}{l}\text { Mempresentasikan hasil diskusi di depan kelas } \\
\text { setelah mengerjakan magic crossword puzzle }\end{array}$ & 2 & 3 & $24 \%$ & Baik \\
\hline 8 & Siswa menanggapi penjelasan dari temannya & 2 & 3 & $23 \%$ & Baik \\
\hline 9 & Siswa mengerjakan lembar evaluasi & 2 & 3 & $24 \%$ & Baik \\
\hline 10 & Siswa berperan serta dalam menyimpulkan & 2 & 3 & $23 \%$ & Baik \\
\hline
\end{tabular}




\begin{tabular}{|c|c|c|c|c|c|}
\hline \multirow[b]{2}{*}{ No } & \multirow{2}{*}{ Aspek Yang Diamati } & \multicolumn{2}{|c|}{ Penilaian } & \multirow{2}{*}{ Persentase } & \multirow{2}{*}{ Ket. } \\
\hline & & $\mathrm{P} 1$ & $\mathrm{P} 2$ & & \\
\hline & $\begin{array}{l}\text { materi pembelajaran } \\
\text { ah Persentse Aktivitas Siswa }\end{array}$ & & & $24 \%$ & Baik \\
\hline
\end{tabular}

\section{Persamaan yang digunakan untuk menentukan aktivitas siswa dan aktivitas guru}

$$
\mathrm{X}_{i}=\frac{\mathrm{P}_{1 i}+\mathrm{P}_{2 i}}{2} \text { dengan } \mathrm{T}_{\mathrm{i}}=\frac{\mathrm{X}_{\mathrm{i}}}{\mathrm{N}} \times 100 \%
$$

(Alfahmi, 2014)

Keterangan :

$$
\begin{aligned}
\mathbf{T}_{\mathbf{i}} & =\text { Presentase frekuensi aktivitas siswabutir ke-1 } \\
\mathbf{X}_{\mathbf{i}} & =\text { Frekuensi aktivitas siswa butir ke-1 hasil pengamatan } 2 \text { orang } \\
\mathbf{P}_{\mathbf{1 i}} & =\text { Hasil pengamatan aktivitas siswa butir ke-1 oleh pengamat } 1 \\
\mathbf{P}_{\mathbf{2 i}} & =\text { Hasil pengamatan aktivitas siswa butir ke-1 oleh pengamat } 2 \\
\mathbf{N} & =\text { Jumlah semua aktivitas siswa }
\end{aligned}
$$

Pengamatan aktivitas siswa dalam pembelajaran dikonversikan dengan kriteria sebagai berikut :

$00,00 \% \leq \mathrm{T}_{\mathrm{i}} \leq 10,00 \% \quad=$ Tidak baik

$10,50 \% \leq \mathrm{T}_{\mathrm{i}} \leq 20,00 \% \quad=$ Cukup Baik

$20,50 \% \leq \mathrm{T}_{\mathrm{i}} \leq 30,00 \%=$ Baik

$30,50 \% \leq \mathrm{T}_{\mathrm{i}} \leq 40,00 \% \quad=$ Sangat Baik

Dapat dilihat pada Tabel 1, bahwa aktivitas siswa pada uji terbatas memperoleh skor 50 dengan persentase $24 \%$ dengan kriteria baik. Walaupun sudah dikatakan kriteria baik, tetapi masih belum

\begin{tabular}{|c|c|c|c|c|c|c|}
\hline $\begin{array}{l}\mathrm{N} \\
\mathrm{o}\end{array}$ & Aspek Yang Diamati & P 1 & P 2 & $\begin{array}{l}\text { Frekuensi } \\
(\mathrm{Xi})\end{array}$ & $\begin{array}{l}\text { Persentase } \\
\text { (Ti) }\end{array}$ & Ket. \\
\hline 1 & $\begin{array}{l}\text { Mengucapkan salam dan menyapa sisiwa } \\
\text { sebelum pembelajaran dimulai }\end{array}$ & 3 & 3 & 3 & $25 \%$ & Baik \\
\hline 2 & Melakukan presensi siswa & 3 & 3 & 3 & $25 \%$ & Baik \\
\hline 3 & Menyampaikan tujuan pembelajaran & 3 & 3 & 3 & $25 \%$ & Baik \\
\hline 4 & $\begin{array}{l}\text { Memotivasi siswa dengan mengajukan } \\
\text { pertanyaan pada awal pembelajaran }\end{array}$ & 3 & 3 & 3 & $25 \%$ & Baik \\
\hline 5 & Menyampaikan materi pembelajaran & 3 & 4 & 3.5 & $29 \%$ & Baik \\
\hline 6 & $\begin{array}{l}\text { Membagi siswa menjadi beberapa } \\
\text { kelompok kecil }\end{array}$ & 2 & 3 & 2.5 & $21 \%$ & $\begin{array}{l}\text { Cukup } \\
\text { Baik }\end{array}$ \\
\hline 7 & $\begin{array}{l}\text { Pemanfaatan media magic crossword } \\
\text { puzzle dan sumber belajar }\end{array}$ & 3 & 3 & 3 & $25 \%$ & Baik \\
\hline 8 & $\begin{array}{l}\text { Membagi lembar kerja kelompok } \\
\text { dengan media magic crossword puzzle } \\
\text { kepada masing-masing kelompok }\end{array}$ & 3 & 4 & 3.5 & $29 \%$ & Baik \\
\hline 9 & $\begin{array}{l}\text { Menjelaskan prosedur pengisian media } \\
\text { magic crossword puzzle }\end{array}$ & 3 & 2 & 2.5 & $21 \%$ & $\begin{array}{l}\text { Cukup } \\
\text { Baik }\end{array}$ \\
\hline 1 & Memantau setiap kelompok saat & 2 & 3 & 2.5 & $21 \%$ & Cukup \\
\hline
\end{tabular}
dikatakan berhasil karena minimal 30\% dari seluruh aktivitas siswa.

Ketidakberhasilan aktivitas siswa menggunakan media magic crossword puzzle karena

Tabel 2. Aktivitas Guru pada Uji Terbatas siswa masih kebingungan menggunakan media magic crossword puzzle. Petunjuk penggunaan media media magic crossword puzzle masih memerlukan revisi kalimat supaya efektif digunakan siswa.

\section{Pengamatan Aktivitas Guru pada Uji Terbatas}

Data aktivitas guru diperoleh dengan mengisi lembar observasi aktivitas guru. Pengamatan aktivitas guru dilakukan oleh peneliti dan observer. Data hasil aktivitas guru pada uji terbatas saat melaksanakan pembelajaran dengan metode demonstrasi menggunakan media magic crossword puzzle disajikan pada Tabel 2. 


\begin{tabular}{|c|c|}
\hline o & Aspek Yang Diamati \\
\hline 0 & $\begin{array}{l}\text { menyelesaikan media magic crossword } \\
\text { puzzle secara bergiliran }\end{array}$ \\
\hline 1 & Mendampingi siswa dalam \\
\hline & $\begin{array}{l}\text { mempresentasikan hasil kerja kelompok } \\
\text { berbentuk media magic crossword puzzle }\end{array}$ \\
\hline & Mengarahkan siswa untuk menarik \\
\hline 2 & $\begin{array}{l}\text { kesimpulan dari pembelajaran yang telah } \\
\text { dilakukan }\end{array}$ \\
\hline & lah Persentase Aktivitas Guru \\
\hline & $\begin{array}{l}\text { Berdasarkan Tabel } 2 \text { aktivitas guru pada } \\
\text { terbatas memperoleh skor } 68 \text { dengan } \\
\text { entase sebesar } 24 \% \text {. Walaupun dikategorikan } \\
\text { namun pembelajaran belum dikatakan } \\
\text { asil karena persentase minimal yang harus } \\
\text { pai sebesar } 30 \% \text {. Hasil aktivitas guru menjadi } \\
\text { r peneliti untuk menjadi guru IPA saat } \\
\text { belajaran menggunakan media magic } \\
\text { sword puzzle di uji skala luas (implementasi } \\
\text { luk). }\end{array}$ \\
\hline
\end{tabular}

\section{HASIL DAN PEMBAHASAN}

\section{Media Magic Crossword Puzzle}

Media magic crossword puzzle yang dikembangkan dalam bentuk persegi ukuran 20 $\mathrm{cm} \times 30 \mathrm{~cm}$ yang terdiri dari bagian depan dan bagian belakang. Bagian depan berupa teka-teki silang dan bagian belakang berupa potonganpotongan gambar. Jika gambar tersebut dirangkai dengan benar akan menjadi sebuah gambar yang padu. Sehingga media ini memiliki dua fungsi, selain sebagai teka-teki silang juga sebagai permainan bongkar pasang.

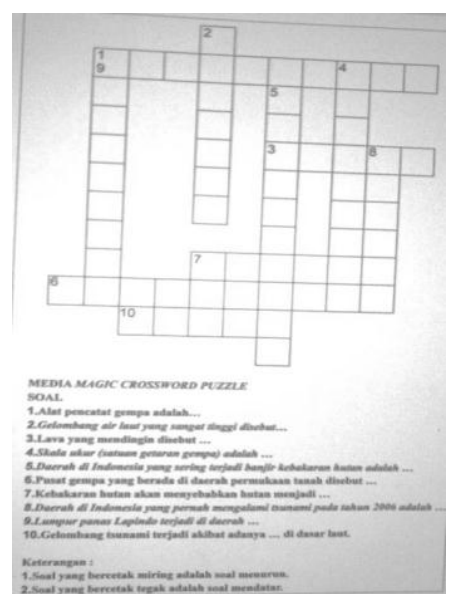

Gambar 2. Bagian Belakang Media Magic Crossword Puzzle

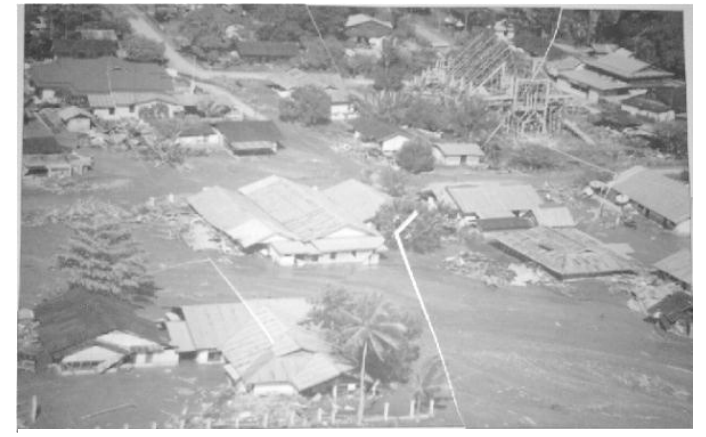

Gambar 3. Bagian Depan Media Magic Crossword Puzzle

\section{Kevalidan Media Transvisi}

Penilaian media magic crossword puzzle dilakukan terdiri dari dua kriteria yaitu criteria I (format media) dan kriteria II (kualitas media). Penilaian kriteria I (format media) meliputi penilaian terhadap 3 komponen yaitu, komponen kelayakan isi, komponen penyajian, dan komponen kegrafikan. Instrumen penilaian kriteria II (kualitas media) juga terdiri dari 3 (tiga) komponen, yaitu komponen kelayakan isi, komponen kelayakan penyajian, dan komponen kelayakan bahasa. Setelah di rata-rata hasil penilaian kriteria I didapatkan nilai $75 \%$ dan ratarata hasil penilaian kriteria II didapatkan nilai 81, $17 \%$. Penilaian terhadap media magic crossword puzzle menunjukkan media magic crossword puzzle valid digunakan untuk siswa kelas $\mathrm{V}$ sekolah dasar.

\section{Keefektifan Media Magic Crossword Puzzle}

Keefektifan media magic crossword puzzle ditunjukkan dari hasil belajar, aktivitas siswa, aktivitas guru dan respon siswa terhadap media magic crossword puzzle. 
Menurut Santoso\&Arthamin, (2010:22) hasil proses pembelajaran adalah perubahan perilaku indiviidu. Individu akan memperoleh perilaku baru, menetap, fungsional, positif, dan disadari. Perubahan perilaku sebagai hasil pembelajaran ialah perilaku secara keseluruhan yang mencakup aspek kognitif, afektif, dan motorik.

Menurut Wagiarti, (2016:14), aktivitas siswa adalah semua kegiatan yang dilakukan siswa selama proses pembelajaran sehingga menimbulkan perubahan perilaku belajar. Perubahan perilaku dapat dikatakan sebagai hasil belajar dan setiap siswa akan memperoleh perubahan perilaku berbeda, tergantung pada penerimaan konsep yang diserap ketika kegiatan pembelajaran. Aktivitas guru merupakan kegiatan yang dilakukan guru selama proses pembelajaran. Dalam proses pembelajaran, guru mempunyai tugas untuk memberikan pengetahuan (cognitive), sikap dan nilai (afective), dan keterampilan (psychomotor) kepada siswa.

Menurut Sujanto (2009:31), respon atau tanggapan diartikan suatu tingkah laku atau sikap yang berwujud baik sebelum pemahaman yang mendetail, penilaian, pengaruh atau penolakan, suka atau tidak serta pemanfaatan pada suatu fenomena tertentu.

Pengamatan hasil belajar siswa dilakukan oleh peneliti berdasarkan nilai pretes dan postes. Pengamatan hasil pretes siswa adalah sebagai berikut.

Tabel 3. Distribusi Nilai Pretes Siswa

\begin{tabular}{llllll}
\hline \multirow{2}{*}{ No } & Tuntas/ Tidak Tuntas & \multicolumn{2}{l}{ Jenis Kelamin } & \multirow{2}{*}{ Jumlah } & Presentase \\
\cline { 3 - 4 } & & $\mathrm{L}$ & $\mathrm{P}$ & \\
\hline 1 & Tuntas & 6 & 4 & 10 & $55,56 \%$ \\
2 & Tidak Tuntas & 4 & 4 & 8 & $44,44 \%$ \\
\hline
\end{tabular}

Keterangan : KKM 60

Pengamatan hasil belajar siswa dilakukan oleh peneliti berdasarkan nilai ulangan harian pada setelah menerapkan magic crossword puzzle. Pengamatan hasil belajar siswa setelah menggunakan media magic crossword puzzle disajikan pada Tabel 4.

Tabel 4. Distribusi Hasil Belajar Siswa pada Setelah menerapkan Magic Crossword Puzzle

\begin{tabular}{llllll}
\hline \multirow{2}{*}{ No } & Tuntas/ Tidak Tuntas & \multicolumn{2}{l}{ Jenis Kelamin } & Jumlah & Prosentase \\
\cline { 3 - 4 } & & $\mathrm{L}$ & $\mathrm{P}$ & \\
\hline 1 & Tuntas & 9 & 8 & 10 & $55,56 \%$ \\
2 & Tidak Tuntas & 1 & 0 & 8 & $44,44 \%$ \\
\hline
\end{tabular}

Keterangan : KKM : 60

Pengamatan Aktivitas Siswa saat Menggunakan Media Magic Crossword Puzzle

Data aktivitas siswa diperoleh dengan mengisi lembar observasi aktivitas siswa. Pengamatan aktivitas siswa dilakukan oleh dua orang pengamat, yaitu peneliti dan guru kelas. Pengamatan aktivitas siswa pada setelah menerapkan magic crossword puzzle diketahui mencapai 38\% dikategorikan sangat baik dan perolehan skor mencapai 80. Dikatakan sangat baik karena persentase aktivitas siswa dari dua pengamat mendekati kriteria aktivitas maksimal yaitu sebesar $40 \%$.

\section{Pengamatan Aktivitas Guru saat Menerapkan Media Magic Crossword Puzzle}

Data aktivitas guru diperoleh dengan mengisi lembar observasi aktivitas guru. Pengamatan aktivitas guru dilakukan oleh guru kelas dan observer. Diperoleh bahwa persentase aktivitas guru setelah menerapkan magic crossword puzzle mencapai 32\% dikategorikan sangat baik dengan perolehan skor 92 .

Penelitian yang dilakukan dengan menerapkan metode demonstrasi menggunakan media magic crossword puzzle dalam pembelajaran IPA Kelas V SD N 2 Gedongmulyo tahun pelajaran 2016/2017 menunjukkan adanya peningkatan hasil belajar 
IPA, hal tersebut menunjukkan bahwa tindakan yang dilakukan berpengaruh terhadap hasil belajar IPA.

\section{Peningkatan Hasil Belajar IPA}

Pelaksanaan pembelajaran IPA setelah menerapkan magic crossword puzzle menunjukkan adanya peningkatan hasil belajar IPA. Jika dibandingkan secara garis besar maka perbandingan rata-rata nilai kelas dan ketuntasan klasikal mengalami peningkatan.

Tabel 5. Perbandingan Rata-rata Nilai dari Pretes ke Postes

\begin{tabular}{llllll}
\hline \multirow{2}{*}{ No } & \multirow{2}{*}{ Hasil belajar } & Pretes & \multicolumn{3}{l}{ Postes } \\
\cline { 3 - 6 } & & Jumlah & $\%$ & Jumlah & $\%$ \\
\hline 1 & Belum tuntas & 8 & 44,44 & 1 & 5,56 \\
2 & Tuntas & 10 & 55,56 & 17 & 94,44 \\
3 & Nilai rata-rata & 57 & & 70 & \\
\hline
\end{tabular}

Keterangan : KKM : 60

Berdasarkan Tabel 5, dapat dilihat bahwa nilai rata-rata klasikal dalam ketuntasan belajar siswa sebelum dan setelah menerapkan magic crossword puzzle dengan jumlah siswa yang tuntas pada hasil pretes yaitu 10 siswa atau sebesar 55,56\%, setelah menerapkan magic crossword puzzle yang tuntas 17 siswa atau sebesar $94,44 \%$. Pada hasil pretes nilai rata-rata kelas hanya mencapai 56,57, kemudian mengalami peningkatan pada setelah menerapkan magic crossword puzzle menjadi
70 dari seluruh siswa yang ada. Terdapat peningkatan hasil belajar siswa setelah menerapkan magic crossword puzzle sebesar $38,88 \%$.

\section{Respon Siswa}

Pelaksanaan pembelajaran IPA dengan metode demonstrasi menggunakan media magic crossword puzzle telah dilaksanakan dengan baik. Berikut data respon siswa mengenai penerapan metode demonstrasi dengan media magic crossword puzzle.

Tabel 6. Persentase Respon Siswa

\begin{tabular}{|c|c|c|c|}
\hline No & Indikator & Ya (\%) & $\begin{array}{l}\text { Tidak } \\
(\%)\end{array}$ \\
\hline 1 & Apakah kamu suka pembelajaran IPA? & $94 \%$ & $6 \%$ \\
\hline 2 & $\begin{array}{l}\text { Apakah pembelajaran IPA dengan media magic } \\
\text { crossword puzzle menarik? }\end{array}$ & $89 \%$ & $11 \%$ \\
\hline 3 & $\begin{array}{l}\text { Apakah kamu lebih senang jika pembelajaran IPA } \\
\text { dengan menggunakan media magic crossword puzzle? }\end{array}$ & $100 \%$ & $0 \%$ \\
\hline 4 & $\begin{array}{l}\text { Apakah pembelajaran IPA dengan menggunakan media } \\
\text { magic crossword puzzle memudahkan kamu memehami } \\
\text { materi? }\end{array}$ & $94 \%$ & $6 \%$ \\
\hline 5 & $\begin{array}{l}\text { Apakah kamu suka jika pembelajaran menggunakan } \\
\text { media magic crossword puzzle diterapkan di sekolahmu? }\end{array}$ & $83 \%$ & $17 \%$ \\
\hline 6 & $\begin{array}{l}\text { Apakah pembelajaran IPA dengan menggunakan media } \\
\text { magic crossword puzzle membuat kamu berani untuk } \\
\text { mengungkapkan pendapat? }\end{array}$ & $83 \%$ & $17 \%$ \\
\hline 7 & Apakah kamu lebih senang belajar kelompok? & $94 \%$ & $6 \%$ \\
\hline 8 & $\begin{array}{l}\text { Apakah kamu senang saat pembelajaran dapat berdiskusi } \\
\text { dengan teman dan guru? }\end{array}$ & $100 \%$ & $0 \%$ \\
\hline 9 & $\begin{array}{l}\text { Apakah media magic crossword puzzle membuat kamu } \\
\text { lebih aktif untuk menjawab pertanyaan yang diberikan } \\
\text { oleh guru? }\end{array}$ & $89 \%$ & $11 \%$ \\
\hline \multirow[t]{2}{*}{10} & $\begin{array}{l}\text { Apakah kamu senang jika hasil kerja kelompok kamu } \\
\text { mendapatkan hadiah dari guru? }\end{array}$ & $94 \%$ & $6 \%$ \\
\hline & Rata-rata & $92 \%$ & \\
\hline
\end{tabular}


Hasil persentase rata-rata respon siswa terhadap penggunaan metode demonstrasi dengan media magic crossword puzzle adalah $92 \%$ siswa mengatakan iya dan dan $8 \%$ siswa mengatakan tidak. Dari hasil tersebut sesuai dengan kriteria persentase respon siswa adalah baik.

\section{SIMPULAN}

Berdasarkan hasil analisis data dapat disimpulkan bahwa (1) media magic crossword puzzle yang dikembangkan dalam bentuk persegi panjang ukuran $20 \mathrm{~cm}$ x $30 \mathrm{~cm}$ yang terdiri dari bagian depan dan bagian belakang. Bagian depan berupa teka-teki silang dan bagian belakang berupa potongan-potongan gambar. Jika gambar tersebut dirangkai dengan benar akan menjadi sebuah gambar yang padu. Sehingga media ini memiliki dua fungsi, selain sebagai teka-teki silang juga sebagai permainan bongkar pasang, (2) media magic crossword puzzle yang dikembangkan memiliki validitas tinggi, berdasarkan hasil penilaian media yang dilakukan oleh 2 validator yang merupakan dosen IPA Universitas PGRI Ronggolawe Tuban. Media yang dikembangkan oleh peneliti termasuk dalam kategori valid dengan rata-rata hasil penilaian kriteria I didapatkan nilai $75 \%$ dan rata-rata hasil penilaian kriteria II didapatkan nilai 81, $17 \%$, (3) penerapan metode demonstrasi dengan media magic crossword puzzle efektif digunakan untuk pembelajaran materi peristiwa alam, dapat dilihat dari ketuntasan klasikal pada nilai pretes yaitu sebesar 55,56\% kemudian pada setelah menerapkan magic crossword puzzle naik menjadi 94,4\%. Aktivitas siswa sebesar $38 \%$ dan aktivitas guru sebesar $32 \%$, menunjukkan media magic crossword puzzle efektif digunakan dalam pembelajaran IPA. Respon siswa terhadap pembelajaran IPA materi peristiwa alam melalui metode demonstrasi dengan media magic crossword puzzle menunjukkan respon yang baik dari siswa kelas V SD N 2 Gedongmulyo.

\section{DAFTAR PUSTAKA}

Alfahmi, Rifqi Wahyudi.2014. Penerapan Model Pembelajaran Kooperatif TGT (Teams Games Tournament) Melalui Media Regas Dalam Meningkatkan Hasil Belajar Siswa Pada Pokok Bahasan Sistem Ekskresi Manusia Di MA Muhammadiyah Paciran Lamongan. Skripsi tidak diterbitkan. Tuban: Program Sarjana Unirow.
Fatimah, M. 2007. Pembelajaran Bervisi SETS Mendukung Pembelajaran Efektif Di Sekolah Dasar. Makalah disajikan pada Seminar Nasional tentang Pembelajaran SETS Di Sekolah Dasar. Semarang: UNNES.

Naryanto, H. S. 2011. Analisis Risiko Bencana Tanah Longsor di Kabupaten Karanganyar, Provinsi Jawa Tengah. Jurnal Penanggulangan Bencana. 2/1: 21-32.

Rakhmadhani, Nuzul, Sri Yamtinah, dan Suryadi Budi Utomo. 2013. Pengaruh Penggunaan Metode Teams Games Tournament Berbantuan Media Teka- Teki Silang dan Ular Tangga Dengan MotVasi Belajar Terhadap Prestasi Siswa Pada Materi Koloid Kelas XI SMA Negeri 1 Simo Tahun Pelajaran 2011/2012. Jurnal Pendidikan Kimia. 2(4) 190-197.

Santoso, Djoko Budi dan M. Sunhaji Arthamin. 2010. Belajar dan Pembelajaran di Sekolah Dasar II. Tuban: UNIROW.

Sapriati, Amalia, Hartinawati, Momon Sulaiman, Ketut Budiastra, Isti Rockiyah, maman Rumanta, Rusna Ristansa, Noehi Nasution, dan Sri Sulistyarini. 2011. Pembelajaran IPA di SD. Jakarta: Universitas Terbuka.

Sudjana, Nana dan Ahmad Rifai. 2009. Media Pengajaran. Bandung: Sinar Baru Algesindo.

Sugiyono. 2010. Metode Penelitian Kuantitatif, Kualitatif dan $R \& D$. Bandung: Alfabeta.

Sujanto, Agus. 2009. Psikologi Perkembangan. Jakarta. Aksara Baru.

Susanto, Ahmad. 2012. Teori Belajar dan Pembelajaran di Sekolah Dasar. Jakarta. Kencana Prenada Media Group.

Susilo, Herawati dan Husnul Chotimah, Yuyun Dwita Sari. 2008. Penelitian Tindakan Kelas Sebagai Sarana Pengembangan Keprofesionalan Guru dan Calon Guru. Malang: Bayumedia Publishing.

Wagiarti. 2016. Implementasi Model Pembelajaran Kooperatif Tipe Two Stay 
Two Stray Untuk Meningkatkan Aktivitas dan Prestasi Belajar Akuntansi Siswa Kelas $X$ Program Keahlian Akuntansi SMK Muhammadiyah 2 Yogyakarta Tahun Ajaran 2015/2016. Skripsi Tidak Diterbitkan. Yogyakarta. UNY.

Wasgito, M. Andi dan Wayan Setiadarma. 2014. Pengembangan Media Permainan Edukatif Teka-Teki Silang (TTS) dalam Proses Pembelajaran Siswa Kelas VII SMP Negeri 2 Kalianget. Jurnal Pendidikan Senirupa. 2(3)36-4 